\title{
CONTRACTUAL ECONOMIC LOSS IN NEW ZEALAND - "WHO, THEN, IS MY NEIGHBOUR" REALLY?
}

\author{
Daniel Kalderimis*
}

This paper is concerned with the issue of when contractual relational economic loss is, and should be, recoverable in New Zealand.

Traditionally this question has been narrowly framed as a debate over whether an ancient legal rule should continue to apply. Recent cases, however, have injected this rule with modern analysis. It has become clear that the debate over the rule is really a debate over which concepts should control negligence liability. This paper examines both the rule and its modern day implications.

The paper examines in turn the New Zealand approach, comparative approaches, and the conceptual underpinnings of the debate. The sophisticated Canadian jurisprudence receives particular emphasis. The conclusion is that not only should New Zealand courts reaffirm the old rule, but that doing so now requires a radical rethinking of the basic New Zealand approach to the law of negligence.

\section{INTRODUCTION}

The Auckland power crisis of 1998 did not merely provide the rest of the country with a rare opportunity to have a guilty laugh at Auckland's expense. It also provided a perfect chance to re-examine the law governing the recovery of negligently inflicted economic loss. Indeed, because of the large financial losses they tend to cause, power failures have

This is an edited version of a paper submitted in fulfilment of the Legal Research and Writing component of the LLB(Hons) degree at Victoria University of Wellington. 
contributed significantly to this area of law. ${ }^{1}$ Thus from a strictly academic point of view, Mercury Energy's commitment to settling claims is rather unfortunate. ${ }^{2}$

The basic problem which economic loss poses for negligence law is familiar. The net of liability thrown by Lord Atkin in Donoghue $v$ Stevenson $^{3}$ is, of itself, far too wide to avoid the oft-mentioned spectre of "liability in an indeterminate amount for an indeterminate time to an indeterminate class". ${ }^{4}$ Various control mechanisms have had to be used in addition to reasonable foreseeability to keep potential liability within realistic boundaries. ${ }^{5}$ In particular, a reluctance to allow the recovery of "pure" economic loss, that is "loss suffered by an individual that is not accompanied by physical or property damage", ${ }^{6}$ has been one of these mechanisms. ${ }^{7}$

The premise underlying all economic loss cases is that some plaintiffs must miss out. Although the amount of economic loss caused in a particular case may well be determinate, a decision to allow recovery for that type of loss can create huge potential liability. The

1 See Seaway Hotels Ltd v Gragg (Canada) Ltd and Consumer Gas Co (1959) 17 DLR (2d) 292; Dominion Tape of Canada Ltd $v$ LR McDonald \& Sons Ltd [1971] 3 OR 627 and Heeney $v$ Best (1979) 28 OR (2d) 71 from Canada; SCM (UK) Ltd $v$ WJ Whittall \& Son Ltd [1971] 1 QB 337 and Spartan Steel \& Alloys Ltd $v$ Martin \& Co Contractors Ltd [1973] 1 QB 27 from England; and NZ Forest Products v A-G [1986] 1 NZLR 76 and Mainguard Packaging Ltd $v$ Hilton Haulage Ltd [1990] 1 NZLR 360 from New Zealand.

2 Mercury Energy announced its "fast-track" compensation scheme on 19 March 1998: "Mercury Energy offer funded by \$20m payout" National Business Review, New Zealand, 27 March 1998, 1. But see "Firms set to give Mercury a jolt" Sunday Star-Times, New Zealand, 17 May 1998, A3; and "Legal aid for business broken by power crisis" Sunday Star-Times, New Zealand, 14 June 1998, A5 which indicate that a class action was still being contemplated. Following the passing of the Electricity Industry Reform Act 1998, Mercury Energy was split into two separately owned companies, named Mercury Energy Ltd and Vector Ltd.

3 [1932] AC 562.

$4 \quad$ Ultramares Corporation v Touche (1931) 174 NE 441, 444 per Cardozo J.

5 This point is made famously by Lord Goff's observation in Smith $v$ Littlewoods Organisation Ltd [1987] 1 AC 241, 280 that "nowadays...the function of the duty of care is not so much to identify cases where liability is imposed as to identify those where it is not" [Smith $v$ Littlewoods].

$6 \quad D^{\prime}$ Amato v Badger (1996) 137 DLR (4th) 129, 132 (SCC).

7 Although Hedley Byrne \& Co Ltd v Heller \& Partners [1964] 2 AC 465 [Hedley Byrne] removed the absolute bar on claims for pure economic loss, the reluctance to allow its recovery has remained in various forms of rigidity. Compare the bright-line exclusionary rule in Murphy $v$ Brentwood District Council [1991] AC 398 [Murphy] with the more flexible attitude of the New Zealand courts which regard economic loss as simply a factor telling against a duty of care: South Pacific Manufacturing v New Zealand Security Consultants \& Investigations Ltd [1992] 2 NZLR 282 [South Pacific]. 
problem is conceptual, rather than factual, indeterminacy. The question is how to draw the line in a principled way.

Recently, this question has been asked with renewed vigour in the context of a particular type of pure economic loss known as 'contractual relational economic loss'. Relational economic loss occurs when a plaintiff suffers economic loss as a "consequence of a physical injury to a third party or damage to the third party's property" but where neither the plaintiff, nor his or her property, has been damaged. ${ }^{8}$ Contractual relational economic loss occurs when the damage affects a contractual right held by the plaintiff. An example of such loss from the Auckland power crisis would be the lost profits of a catering company which was unable to provide food at a function because its supplier's unrefrigerated stocks had spoilt.

Traditionally, the recoverability of this type of loss has been framed as a decision about whether a certain old legal rule should apply. Recent cases, however, have injected this rule with modern analysis. These cases have recognised that contractual relational economic loss is, in many ways, a marker for all economic loss. This is because - being so commonly caused - contractual relational economic loss raises the fundamental indeterminacy problem in acute form.

The result is that contractual relational economic loss has been revisited, but with a far broader focus. The focus has moved from precedent to approach. The question of when this type of loss should be recoverable has turned into a debate over the very concepts which control negligence liability.

This paper is divided into three main parts. Part II examines the current legal position in New Zealand with reference to inherited English precedent. It concludes that New Zealand law is unclear as the cases reveal two conflicting lines of authority. Part III discusses the approaches of Australia and Canada with particular emphasis on the sophisticated Canadian jurisprudence. Part IV analyses these approaches and then suggests the direction New Zealand law should take. It concludes that not only should New Zealand courts reaffirm the old rule, but that doing so now requires a radical rethinking of the basic New Zealand approach to negligence law.

\section{THE NEW ZEALAND POSITION}

\section{A The Prima Facie Position}

At first glance, the question of when contractual relational economic loss is recoverable may seem easy to answer. The Court of Appeal in the cases of Brown v Heathcote County 
Council ${ }^{9}$ and South Pacific Manufacturing Co Ltd $v$ New Zealand Security Consultants $\mathcal{E}$ Investigations $L t d^{10}$ has directly addressed the issue of when a duty of care should be held to exist. Both cases essentially affirm the two-step approach in Anns $v$ Merton Borough Council $^{11}$ and emphasise that the critical decision of whether to allow recovery is always a policy one based on "whether it is just and reasonable to uphold a duty of particular scope". ${ }^{12}$ This is a question of "mixed law and fact"13 which requires consideration of a wide range of different factors. ${ }^{14}$

Negligence law is therefore governed by policy and not by hard and fast rules. Accordingly, Cooke P in particular has made it clear that "the fact that economic loss rather than personal physical injury has been suffered may weigh against a duty of care, but is certainly not decisive per se". ${ }^{15}$ Thus contractual relational economic loss would appear to be recoverable when justified on policy grounds, and irrecoverable when not.

There is High Court support for this approach. Two High Court cases, both involving claims for relational economic loss caused by interruptions to a power supply, allowed recovery. The first is New Zealand Forest Products Ltd $v$ Attorney-General. ${ }^{16}$ In this case Post Office workers accidentally cut through an electricity cable which was owned by the Thames Valley Electric Power Board, but supplied electricity solely to the plaintiff's mill. No damage was caused to the plaintiff's property, but the plaintiff lost money through the mill being out of production.

Barker J had little hesitation in rejecting the majority decision from the English Court of Appeal case of Spartan Steel $\mathcal{E}$ Alloys Ltd $v$ Martin $\mathcal{E}$ Co (Contractors) $L t d .{ }^{17}$ This case, in very similar circumstances, allowed the plaintiff to recover for economic loss consequent on physical damage it suffered but not for pure economic loss sustained by being out of

[1986] 1 NZLR 76 [Brown].

10 South Pacific above $\mathrm{n} 7$.

11 [1978] AC 728, 751-752 [Anns]. See Brown above n 9, 78 per Cooke P; and South Pacific above n 7, 295-297 per Cooke P and 305 per Richardson J.

12 South Pacific above n 7, 297 per Cooke P.

13 South Pacific above n 7, 293 per Cooke P.

14 South Pacific above n 7, 290-299 per Cooke P.

15 South Pacific above n 7, 296 per Cooke P. See also Brown above n 9, 79 per Cooke P: "We have also recognised that, if the loss in question is merely economic, that may tell against a duty" .

16 [1986] 1 NZLR 14 [New Zealand Forests].

17 [1973] 1 QB 27 [Spartan Steel]. 
production. Barker J regarded this distinction as being "without logic"18 and allowed recovery as the plaintiff's economic loss was reasonably foreseeable to the defendant.

In the second case, Mainguard Packaging Ltd $v$ Hilton Haulage $L t d^{19}$ the defendant transport company reversed into a power pole supplying electricity to the plaintiff factory. This caused a power surge closely followed by a power cut. The former started a fire in the plaintiff's sales office and the latter kept the plaintiff's factory out of action for 24 hours. It was accepted that this latter loss was not consequent on any physical damage. Tipping J found that Hilton owed a duty to Mainguard and that both types of loss flowed directly from Hilton's breach of this duty. His Honour therefore allowed recovery. Again, although contractual relational economic loss was sustained, his Honour did not regard this fact as significant. ${ }^{20}$

\section{B The Exclusionary Rule}

The law is, however, not as simple as these cases make it appear. The reason for this is a long line of authority beginning around 1875. The classic starting point is Cattle $v$ The Stockton Waterworks $\mathrm{Co}^{21}$ involving a plaintiff who had contracted to build a tunnel on a third party's land. Due to the negligence of the defendant, the tunnel flooded and this put the plaintiff to extra expense. Blackburn J dismissed the plaintiff's action on the basis that a mere contractual interest in damaged property does not give a right to sue for its damage.

This principle has been consistently affirmed over time. ${ }^{22}$ Through later cases it has hardened into an exclusionary rule that in order to sue for damage to property, a plaintiff

New Zealand Forests above n 16, 17.

19 [1990] 1 NZLR 360 [Mainguard].

20 Despite Tipping J's treatment of the case as identical to New Zealand Forests, it is less strong because Mainguard did suffer physical damage. Thus it is possible (although difficult) to view it not as a relational loss case, but as a consequential loss case which adopts a wider rule for recovery than that applied in Spartan Steel. This would make it similar to the Ontario Court of Appeal decision in Seaway Hotels Ltd v Gragg (Canada) Ltd and Consumers' Gas Co (1959) 17 DLR (2d) 292 where a hotel, due to severed power cables, suffered lost profits as well as damage to food which spoilt. The fact of physical damage was " the hook upon which liability was hung for the entire loss": Hon Allen Linden Canadian Tort Law (5ed, Carswell, Toronto, 1993) 385. Italics in original.

21 (1875) LR 10 QB 453 [Cattle].

22 See Simpson \& Co $v$ Thompson (1877) 2 App Cas 279; La Societe de Ramorquage a Helice $v$ Bennetts [1911] 1 KB 243; Elliot Steam Tug Co Ltd v Shipping Controller [1922] 1 KB 127; Weller \& Co v Foot and Mouth Disease Research Institute [1966] 1 QB 569; and Margarine Union GmbH v Cambay Prince Steamship Co Ltd (The Wear Breeze) [1969] 1 QB 219. 
must have either a possessory ${ }^{23}$ or a legal proprietary interest in the property. The rule thus specifically precludes contractual relational economic loss and is therefore inconsistent with the result in the New Zealand Forests case and probably the Mainguard case also. ${ }^{24}$

Importantly, far from being a legal anachronism dated by the complexity of modern negligence law, the exclusionary rule has been directly affirmed twice in the last 15 years by the Privy Council and the House of Lords respectively.

Both cases involve rather complicated facts. Candlewood Navigation Corporation Ltd $v$ Mitsui OSK Lines Ltd (The Mineral Transporter) ${ }^{25}$ was decided in 1986 by the Privy Council. The first plaintiff in this case was the owner of a vessel named the Ibaraki Maru and let her to the second plaintiff by a demise charter. The second plaintiff then let the Ibaraki Maru back to the first plaintiff by a time charter. The vessel was damaged when another vessel negligently collided with her. Both plaintiffs claimed damages. The second plaintiff was liable under its contract with the owner (who was of course the first plaintiff) to repair the ship. It recovered this loss from the defendant. Whilst under repair, the first plaintiff was liable to pay a reduced hire rate but could not use the Ibaraki Maru during this time. It sued for both the wasted hire cost and its lost profits. ${ }^{26}$

23 Possession is a fairly ill-defined common law concept. Legal possession is more than merely possession in fact. The "intention with which that possession is exercised needs to be considered as well": Robby Bernstein Economic Loss above n 8, 135. Further, it is unclear whether actual possession is required by this rule, or whether a "right to possession" is sufficient. The following cases have tentatively indicated the latter: Chabbra Corporation Pte Ltd v Jag Shakti [1986] AC 377 and Transcontainer Express Ltd $v$ Custodian Security Ltd [1988] 1 Lloyd's Rep 128.

24 This rule should not be confused with the broad exclusionary rule laid down by the House of Lords in Murphy $v$ Brentwood District Council (above n 7) which, subject to limited exceptions such as Hedley Byrne, above n 7, disallowed all claims for pure economic loss. This broad rule is certainly not a part of New Zealand law: Invercargill City Council v Hamlin [1996] 1 NZLR 513. However, as La Forest J noted in Canadian National Railways v Norsk Pacific Steamship Co (1992) 91 DLR (4 $\left.4^{\text {th }}\right) 289,308$ : "the precedents support a distinct approach to the issue of contractual relational economic loss." All references to "the exclusionary rule" in this paper are to the narrow rule laid down in Cattle (above $\mathrm{n} 21$ ). otherwise would have been. It did not suffer any loss as owner of the ship. 
The Committee denied the first plaintiff's claims and upheld the exclusionary rule. Lord Fraser adopted the classic statement of the rule given by Scrutton LJ in Elliot Steam Tug Co Ltd v Shipping Controller: ${ }^{27}$

At common law there is no doubt about the position. In case of a wrong done to a chattel the common law does not recognise a person whose only rights are a contractual right to have the use or services of a chattel for purposes of making profits or gains without possession or property in the chattel.

As a time charter gave only a contractual and neither a possessory or proprietary right to use the Ibaraki Maru, the first plaintiff had no standing to sue. ${ }^{28}$

The House of Lords emphatically reaffirmed this decision less than a year later in another maritime case, Leigh and Sillavan Ltd $v$ Aliakmon Shipping Co Ltd (The Aliakmon). ${ }^{29}$ The damage in this case was to cargo negligently carried in the defendant's ship. The plaintiff was the buyer of this cargo under an unusual c.i.f. agreement. Usually such a contract provides for the risk in the goods to pass to the buyer upon shipment and for property to pass when the buyer collects the shipping documents, including the bill of lading. By statute, where property passed through the seller's endorsement of the bill of lading, acquisition of this document gave the buyer full rights to sue under the seller's original contract of carriage. ${ }^{30}$ This would have given the plaintiff the right to sue for the damage to the cargo.

However, due to the plaintiff's difficulties in paying for the goods the agreement was importantly varied. The seller reserved title in the goods until payment. This prevented property from passing through the seller's endorsement of the bill of lading together with its concomitant rights of suit. The unfortunate effect of this was that at the time of damage, the plaintiff had the risk but not the legal property in the goods. Thus, although the owner of the goods had a right to sue, only the plaintiff had suffered loss. Despite this, the Board above $\mathrm{n} 25,15$. See also 25 of the same case.

28 The reason that the plaintiff did not have a possessory interest, even though it was using the boat, was because of a technicality of maritime law. It is established that only a demise charter gives a possessory interest. The major difference between a time charter and a demise charter is that, under the latter, the master and the crew become employees of the charterer. The former simply gives the charterer a contractual right to their services. See Bernstein Economic Loss above $\mathrm{n} 8,135$; and above $\mathrm{n} 23$ generally.

29 [1986] AC 785 [The Aliakmon].

$30 \quad$ Bill of Lading Act 1855 (UK), 18 \& 19 Vic, c 111, s 1. 
held that the plaintiff had no cause of action. The Board stated that even if the plaintiff had an equitable interest in the goods, such an interest is insufficient to give title to sue. ${ }^{31}$

\section{The Exclusionary Rule in New Zealand}

The exclusionary rule, far from having decayed in unread law reports, is alive and well. What is more there are indications it does apply in New Zealand. First, it was applied in the High Court decision of Seddon $v$ Ryans Carriers $L t d{ }^{32}$ In this case the plaintiff sued to recover for damage caused to her garden by a truck which crashed into it. What made this case interesting is that the garden was not actually the plaintiff's property, but part of the Wellington Town Belt. The case proceeded upon the assumption that due to Cattle and The Aliakmon either legal title or possession had to be established to enable the plaintiff to sue. $^{33}$

Second, the exclusionary rule has been referred to on more than one occasion by the Court of Appeal. In Williams $v$ Attorney-General, 34 a case which Todd described as "worthy of rather an ingenious exam question", 35 the Court had to address the rule directly. In this case the plaintiff's boat The Nomad was used, unbeknown to the plaintiff, by a prospective purchaser to import heroin into New Zealand. The purchaser was arrested and The Nomad was seized by the Customs Department. Under the Customs Act 1966, property in the vessel was forfeited to the Crown. Williams tried, and after three years succeeded, in getting the forfeiture unconditionally waived by the Minister of Customs. However during this time The Nomad had been neglected, suffering water damage and vandalism.

The question was simply whether the Crown owed a duty of care to Williams even though, at the time of the damage, Williams had neither ownership nor possession of the vessel. The Court held 3-2 that it did. Richardson and Casey JJ dissenting, held that the exclusionary rule applied and denied recovery. ${ }^{36}$ The majority allowed recovery on the

31 The Aliakmon above n29, 813. Incidentally, in response to the perceived injustice of this decision s 2(1) of the Carriage of Goods by Sea Act 1992 (UK) - the successor to the Bills of Lading Act 1855 - was enacted to give the rights of suit to all holders of the bill of lading, irrespective of whether or not property passed through endorsement of the bill.

32 Seddon v Ryans Carriers Ltd (3 February 1995) unreported, High Court, Wellington Registry, CP 82/91, Gallen J [Seddon v Ryans Carriers Ltd].

33 Seddon $v$ Ryans Carriers Ltd above n 32, 10.

34 Williams v Attorney-General [1990] 1 NZLR 646.

35 Stephen Todd "Duties of care: the New Zealand Jurisprudence Part 2: Particular Duty Problems" (1993) 9 Professional Negligence 54.

36 Williams v Attorney-General above n 34, 679 per Richardson J; 687 per Casey J. Although Richardson J emphatically upheld the rule Casey J relied more heavily on the statutory scheme than on the rule. 
basis that sufficient proximity existed between the parties to justify a duty of care. Although this reasoning suggests that the exclusionary rule was rejected in favour of a more flexible approach, all three majority judges were careful to distinguish, rather than disagree with, The Mineral Transporter and The Aliakmon. Each Judge reasoned that the unique statutory background to the present case reduced those authorities to limited assistance. ${ }^{37}$ In fact both Cooke $\mathrm{P}$ and Bisson J went to some lengths to reconcile the result with the exclusionary rule, holding that the Customs Act actually gave Williams a property interest in The Nomad whilst it was forfeited. ${ }^{38}$

The other Court of Appeal reference is Cooke P's comment in Brown v Heathcote County Council that: ${ }^{39}$

[t]here appears to be nothing in any New Zealand decision contrary to the decisions of the

Privy Council and the House of Lords in The Mineral Transporter and The Aliakmon.

This is questionable, and at the time it was written appears to have been inaccurate as the New Zealand Forests case had been decided more than a year earlier. But if the President's gloss was a slight oversight, Barker J's failure in New Zealand Forests to even refer to any of the exclusionary rule cases was, with respect, a major mistake. It appears that - perhaps because the relevant authorities were not put to him - Barker J did not recognise that he was dealing with a textbook relational economic loss case. His Honour's judgment is essentially a rejection of the majority approach in the Spartan Steel case which he regarded as "in pari materia with the present". ${ }^{0}$ But the two cases are not the same. The crucial difference is that physical damage was caused to the plaintiff in Spartan Steel, but none was caused to the plaintiff in New Zealand Forests. Spartan Steel was a consequential loss case; New Zealand Forests, a relational loss case.

Of course a New Zealand court may at some time rule that the distinction between consequential and relational loss is without substance. However until then, different rules govern the different losses. Barker J's judgment simply considers the wrong set of cases. The result he reaches can be contrasted with that reached by the Scottish Court of Session in Dynamco Ltd $v$ Holland and Hannen \& Cubitts (Scotland) $L t d^{41}$ which, on identical facts (a plaintiff company suing for loss of profits following the negligent damage of their electricity supply cable) applied the exclusionary rule to deny recovery.

\footnotetext{
37 Williams v Attorney-General above n 34, 672 per Cooke P; 685 per Somers J; and 691 per Bisson J.

38 Williams v Attorney-General above n 34, 672 per Cooke P; 692 per Bisson J.

39 Brown above n 9, 79-80.

40 New Zealand Forests above n 16, 16.

41 Dynamco Ltd $v$ Holland and Hannen \& Cubitts (Scotland) Ltd [1972] SLT 38.
} 
The current law in New Zealand is thus extremely unclear. This was highlighted by a recent District Court case which involved very similar facts to The Mineral Transporter - a plaintiff time charterer suing for repair costs and lost profits occasioned by the defendant's negligent damage to the time chartered vessel. The case, Toho Line Ltd v Kaimai Stevedore Services $L t d{ }^{42}$ was an application by the defendant to strike out the plaintiff's claim. The Court refused to do so. Among its reasons it stated that the New Zealand approach has moved in a "case-by-case" direction inconsistent with the rigid application of the exclusionary rule. ${ }^{43}$ The Court then doubted whether on the current state of New Zealand law "The Mineral Transporter decision is either binding on New Zealand Courts or is even applicable". ${ }^{4}$ Surely this puts the issue a little too strongly, but it can be read as a timely indication of the real uncertainty in New Zealand law.

This is an issue which cries out for rigorous judicial attention. New Zealand's flexible approach to negligence law sits very uncomfortably with the continued existence of a rule requiring a proprietary or possessory interest in damaged property to sue in respect of damage to it. However this rule has been well entrenched in the common law for over 100 years, and far from being overruled in this country, it has received tacit encouragement at regular intervals. To return to the power crisis which sparked this discussion, if Mercury Energy were to be sued by a party suffering only contractual relational economic loss, it is far from clear which side would win.

\section{COMPARATIVE APPROACHES}

This part of the paper will explore the different approaches to contractual relational economic loss taken by overseas jurisdictions. The frame of reference is the English approach which has already been outlined in some detail. ${ }^{45}$ This section will first address

42 Toho Line Ltd v Kaimai Stevedore Services Ltd [1996] DCR 524 [Toho].

43 Toho above $\mathrm{n} 42,536$. This is a view shared by Stephen Todd "Duties of care: the New Zealand Jurisprudence Part 2: Particular duty problems" above n 35, 55.

44 Toho above $\mathrm{n} 42$, 537. The Court questioned whether the rule in Bruer $v$ Wright [1982] 2 NZLR 77, that Privy Council decisions are generally to be considered binding in all Commonwealth courts or the exception for divergent local circumstances illustrated by Invercargill City Council $v$ Hamlin [1996] 1 NZLR 513, was most applicable to this issue: 536-537.

45 English case law does contain one important exception to the exclusionary rule in the case of Morrison Steamship Co Ltd v Greystoke Castle (Cargo Owners) [1947] AC 265 (HL) [Greystoke]. In this case two ships collided, both sustaining damage. The plaintiff was the owner of cargo carried on one of them. Although the plaintiff's cargo was not damaged, the plaintiff was contractually liable to contribute in general average with the owner of the ship for the cost of repair to the ship. The House held that an exception to the exclusionary rule exists where two parties are engaged in a "common adventure" (see 280 per Lord Roche; 296 per Lord Porter). The plaintiff was therefore able to recover its share of the repair costs. 
the law in Australia which has moved in a different direction. It will then, in deference to the significant judicial attention this issue has recently received there, more extensively review the Canadian developments.

\section{A Australia}

The High Court of Australia appeared to reject the exclusionary rule in the landmark case of Caltex Oil (Australia) Pty Ltd $v$ The Dredge "Willemstad".46 In this case the defendant's dredge negligently fractured a pipeline belonging to a third party, AOR. The plaintiff, Caltex, used this pipeline for transporting oil from AOR's refinery to its terminal. The oil in the pipeline was the property of Caltex. Caltex sued the defendant for the economic loss it suffered by having to re-route its oil by land. The five member bench unanimously allowed recovery, although each member found for different reasons.

Despite their apparent disagreement, each Judge essentially applied a type of proximity test and found that Caltex and AOR were so closely linked that either an exception should be made to the rule (Gibbs and Jacobs JJ), ${ }^{47}$ or the rule should be rejected (Murphy, Mason and Stephen JJ). ${ }^{48}$ Stephen J made this process explicit, ruling that the concept of proximity was a more appropriate control mechanism of indeterminate liability than a doctrinaire distinction between economic and physical damage. ${ }^{49}$ In doing so, his Honour emphasised a point crucial to this paper. This is that the debate over the exclusionary rule is really a debate over the core concepts which limit liability. Stephen J openly treated this issue as a decision whether proximity or damage type should be the primary control of liability in negligence.

Clearly, the Caltex decision did not present a united front - so much so that the House of Lords in The Mineral Transporter refused to accept the case as a rejection of the exclusionary rule. ${ }^{50}$ Very few would advance this proposition today. Karen Hogg argues

46 (1976) 136 CLR 529 [Caltex].

47 Gibbs J created an exception where the defendant knows that the plaintiff " will be affected individually, and not merely as a member of an unascertained class": Caltex above n 46, 555. Jacobs J, on the other hand, confined the exclusionary rule to the loss of a contractual benefit and held that it did not apply where the defendant's negligence has a "physical effect" on the plaintiff: Caltex above n 46, 601.

48 Murphy J shortly stated that he saw no reason why it should apply: Caltex above n 46, 606; Mason J held that Hedley Byrne, above $\mathrm{n}$ ? had ramifications beyond the area of negligent misstatement and that the exclusionary rule is based on "an absolute distinction between property damage and economic damage which is difficult to justify": Caltex above n 46, 591; and Stephen J applied a proximity test: see text and below $n 49$.

49 Caltex above $\mathrm{n} 46,574-575$ per Stephen J.

50 The Mineral Transporter above n 25, 24. 
that "it would be unrealistic, if not absurd, to suggest that the High Court would now retreat from the Caltex decision and reaffirm the traditional exclusory rule". ${ }^{1}$ She argues that the received interpretation of Caltex is in accordance with Stephen J's judgment: there is no absolute bar on the recovery of relational loss. Liability is instead decided by applying the proximity principle.

\section{B Canada}

Contractual relational economic loss has been closely debated in Canada. In fact, it has been the subject of two recent Supreme Court decisions: Canadian National Railways Co $v$ Norsk Pacific Steamship Co ${ }^{52}$ and Bow Valley Husky (Bermuda) Ltd v Saint John Shipbuilding $L t d{ }^{53}$ Each will be addressed in turn.

\section{Norsk}

The Norsk case involved relatively simple facts. In foggy weather, the defendant's tug negligently collided with a railway bridge. The plaintiff, Canadian National Railways (CNR), was the principal user of this bridge and accounted for around $85 \%$ of traffic across it. It also owned land and rail tracks close to either side of the bridge. It had used the bridge continuously since 1915 and many people (including the captain of the tug) believed CNR to own it. However it did not own the bridge, but contracted to use it from the owner, the Canadian Government. This contract (unlike those made with the other three railway companies using the bridge) required CNR to undertake general maintenance work and to make any necessary repairs to the bridge at Canada's expense. CNR also arranged inspections of the bridge from time to time and provided consulting services to Canada free of charge. In the case of damage to the bridge the contract totally excluded Canada's liability to CNR. CNR sued Norsk for its added costs in re-routing its trains over an upstream bridge and sometimes by land.

The scenario was thus very similar to the Caltex case. The result was also similarly, but not as extensively, fragmented. The Supreme Court found by a 4-3 majority for CNR. However, its reasoning was split three ways. McLachlin J (L'Heureux-Dubé and Cory JJ concurring) delivered the main majority judgment. The fourth majority Judge was Stevenson J, who found for CNR for different reasons. The dissent was delivered by La Forest J (Sopinka and Iacobucci JJ concurring). Both McLachlin and La Forest JJ expressly

51 Karen Hogg "Relational Loss, the Exclusory Rule and the High Court of Australia" (1995) 3 Tort L Rev 26, 36.

52 (1992) 91 DLR $\left(4^{\text {th }}\right) 289$ [Norsk].

53 (1998) $153 \operatorname{DLR}\left(4^{\text {th }}\right) 385$ [Bow Valley]. 
rejected Stevenson J's reasoning. ${ }^{54}$ The result was, therefore, that no more than three of the seven judges supported any single ratio. Both the main majority judgment and the dissent present powerful, reasoned arguments. This paper shall address each in turn.

\section{(a) McLachlin J's judgment}

McLachlin J defined the issue as "the extent to which damages for pure economic loss may be recovered in tort at common law". ${ }^{55}$ After reviewing the developments in other jurisdictions, her Honour identified "two different approaches to the problem of defining the legal parameters of common law rules": ${ }^{66}$ the bright-line exclusionary approach as applied in Murphy; and the proximity based, case-by-case approach as applied in Anns. Her Honour firmly adopted the latter approach. Thus her test is the familiar two-step process: proximity is a necessary, but not sufficient, condition of liability which may be negatived by policy considerations. ${ }^{57}$ She stated: ${ }^{58}$

Proximity is the controlling concept which avoids the spectre of unlimited liability. Proximity

may be established by a variety of factors, depending on the nature of the case.

Proximity, then, was McLachlin J's solution to the indeterminacy problem. This solution is a universal concept "capable of subsuming different categories of cases involving different factors". 59

Applying this test to the facts, her Honour found firstly that CNR was in close physical proximity to the bridge by virtue of its land ownership on either side and also by its high use of the bridge, such that its trains were actually in danger of physical injury by the accident. ${ }^{60}$ The fact that this did not eventuate was irrelevant. More importantly McLachlin J emphasised the proximity between CNR and the direct victim, Canada. She concluded that CNR's obligations to Canada brought their relationship into the joint venture category recognised in such cases as Greystoke. ${ }^{61}$ As there were no overwhelming

54 Stevenson J rejected the exclusionary rule and applied the "known plaintiff" test, similar to that applied by Gibbs J in Caltex. La Forest J described this as placing "a premium on notoriety": Norsk above n 52, 342, a description adopted by McLachlin J: Norsk above n 52, 377.

$55 \quad$ Norsk above n 52, 358.

56 Norsk above n 52, 366.

$57 \quad$ Norsk above n 52, 371.

$58 \quad$ Norsk above n 52, 369.

$59 \quad$ Norsk above n 52, 368.

60 Norsk above n 52, 368

61 Above $\mathrm{n} 45$. 
policy reasons to deny recovery, CNR was entitled to recover. Ultimately, McLachlin J characterised her approach as fair and flexible, unfettered by absolute rules based on different categories of loss.

\section{(b) La Forest J's judgment}

La Forest J's approach began with a narrower question than that of his colleague. His Honour stated the issue as whether contractual relational economic loss is recoverable. ${ }^{62}$ Thus his judgment distinguishes its approach to limiting liability from McLachlin J's from the outset. Instead of treating all economic loss as an homogenous group, his Honour is concerned to deal with the peculiarities of relational economic loss. La Forest J explained the reason for this approach: ${ }^{63}$

To phrase the key issue in this case as a simple one of "is pure economic loss recoverable in tort?" is misleading. I do not doubt that pure economic loss is recoverable in some cases. It does not follow, however, that all economic loss cases are susceptible to the same analysis, or that cases of one type are necessarily relevant to cases of another...The fact is that different types of factual situations may invite different approaches to economic loss, and it seems to me to be at best unwise to lump them all together for purposes of analysis.

In taking this approach, La Forest J acknowledged his debt to the work of Feldthusen whose article "Economic Loss in the Supreme Court of Canada: Yesterday and Tomorrow"164 argued that all economic loss is not identical and can be divided up into five distinct categories, each presenting unique policy considerations. ${ }^{65}$ La Forest J adopts Feldthusen's argument that the fifth category - (contractual) relational economic loss -

$62 \quad$ Norsk above n 52, 291.

63 Norsk above n 52, 299.

64 Bruce Feldthusen, "Economic Loss in the Supreme Court of Canada: Yesterday and Tomorrow" (1991) 17 CBLJ 356.

65 Norsk above n 52, 299-300. The categories are: the independent liability of statutory public authorities; negligent misrepresentation; negligent performance of a service; negligent supply of shoddy goods or structures; and relational economic loss. La Forest J slightly rearranges them into a broad three-category structure of (1) consequential loss cases; (2) non-relational loss cases (into which Feldthusen's categories 1-4 belong); and (3) contractual relational economic loss: Norsk, above n 52, 302. See generally Bruce Feldthusen Economic Negligence (2ed, Toronto, Carswell, 1989); Bruce Feldthusen and John Palmer "Economic Loss and the Supreme Court of Canada: an Economic Critique of Norsk Steamship and Bird Construction" (1995) 74 Can Bar Rev 427; and Bruce Feldthusen "The Recovery of Pure Economic Loss in Canada: Proximity, Justice, Rationality, and Chaos" (1996) 24 Manitoba LJ 1 [Recovery of Pure Economic Loss in Canada]. 
should be barred by an exclusionary rule. ${ }^{66}$ This is because of the important differences between contractual relational economic loss and other pure economic loss.

Firstly, it is by definition a secondary liability - the tortfeasor is already liable to the victim of the physical damage. This means that the deterrence goal of tort law is at least partially fulfilled without need for further litigation. Secondly, La Forest J argued that an exclusionary rule does not deprive the plaintiff from compensation. It merely "channels" the plaintiff's claim towards the property owner. If the contract between the two excludes the owner's liability, this will most likely be because the parties are agreed that the plaintiff "is in the best position to insure the risk at the lowest cost". 67 Thirdly, his Honour observed that there is a much bigger pool of contractual relational economic loss claimants than persons suffering other pure economic loss.

Applying the exclusionary rule to CNR's claim, La Forest J identified an exception for joint venture cases. However his Honour disagreed that CNR was engaged in a joint venture with Canada. The reason was that under the contract, $\mathrm{CNR}$ was not required to contribute to Canada's loss. His Honour pointed out that CNR did not have to perform any service without payment. ${ }^{68}$

La Forest J also rejected CNR's argument that it had an alternative interest in the bridge by virtue of the "transferred loss" doctrine. This exception to the exclusionary rule whereby the property owner's loss is transferred to the plaintiff was forcefully argued by Robert Goff LJ in the dissenting judgment of the English Court of Appeal decision in The Aliakmon. ${ }^{69}$ His Honour defined transferred loss as loss which would ordinarily fall on the owner of the goods, falling on the buyer in circumstances where the owner may lack the incentive to enforce its right of action. ${ }^{70}$ The House of Lords rejected this exception. ${ }^{71}$

La Forest J did not actually state whether transferred loss is a true exception to the rule. He did, however, hold that such loss only occurs where the risk of property damage has passed, but the right to the property has not. ${ }^{72} \mathrm{CNR}$ 's loss was not transferred because

66 Feldthusen's category included all relational economic loss. La Forest J's judgment was confined to contractual relational economic loss, which was the only loss suffered by CNR.

$67 \quad$ Norsk above $\mathrm{n} 52,302$.

68 Norsk above n 52, 334.

69 The Aliakmon [1985] 1 QB 350 [The Aliakmon CA].

70 The Aliakmon CA above $\mathrm{n} 69,396$ per Goff LJ.

71 The Aliakmon above n 29, 819-820.

72 The reason for this narrow definition is that every contract to use an asset assigns some of the property owner's rights to the contracting party. Thus damage caused by interference with any contractual right over property is all, in a sense, transferred loss. 
it never assumed the risk of property damage. Canada was clearly required to pay for repairs to the bridge and it did so. CNR's claim was purely for loss of use.

It followed that CNR had nothing more than a contractual right to use the bridge. Finally his Honour examined arguments that for special reasons a new exception to the exclusionary rule should be made. His Honour made it clear that a new exception would only be made where the plaintiff could: $:^{73}$

...respond effectively not only to the concern about indeterminacy but also show that no

adequate alternative means of protection was available.

His Honour shortly disposed of the argument that the indeterminacy problem was not an issue as it was widely known that CNR used the bridge. ${ }^{74}$ He stated that such knowledge is in principle irrelevant to who should recover for contractual relational economic loss. His Honour then addressed CNR's alternative means of protection. He concluded that CNR was clearly in the best position to guard against the loss it suffered. La Forest J observed that both CNR and Canada were sophisticated contracting parties, well aware of the risk of bridge failure and the losses this could cause CNR. Indeed previous damage of the same bridge had been the subject of earlier (unsuccessful) litigation by CNR: Gypsum Carrier Inc v The Queen. ${ }^{75}$

Essentially, La Forest J held that CNR should have built the price of insurance for loss into its contract with Canada. He saw no reason why CNR and Norsk should both have to insure for contractual relational economic loss, which he argued would be the outcome of McLachlin J's case-by-case proximity test.

\section{(c) The two approaches in perspective}

Both judgments were openly trying to do the same thing - find a principled solution to the indeterminacy problem. At their narrowest they differ only on the definition of a joint venture: La Forest J's is tightly contractual; McLachlin J's is more pragmatic. However this superficial similarity obscures the very different reasoning each Judge employed. As noted, McLachlin J adopted an Anns-style test as the mechanism for controlling indeterminate liability. The touchstone of this is the concept of proximity. McLachlin J explicitly rejected strict rules based on different types of damage.

$73 \quad$ Norsk above n 52, 355.

$74 \quad$ Norsk above n 52, 339-340.

75 Gypsum Carrier Inc $v$ The Queen (1977) 78 DLR (3d) 175. 
La Forest J, by contrast, dismissed proximity as expressing a result rather than a principle. ${ }^{76}$ His control mechanism is based on the type of damage suffered. However, not only did his Honour embrace the physical/economic damage distinction underlying the exclusionary rule, he made it far more sophisticated. La Forest J's entire approach is concerned with breaking economic loss itself into different subsets which further regulate recovery.

\section{Bow Valley}

This case was the Supreme Court's opportunity to clear up the uncertainty created by its decision in Norsk. ${ }^{77}$ It took it. The lead judgment is delivered by McLachlin J with La Forest J concurring. Her analysis of the contractual relational economic loss issue in the case is also accepted by the other judgment, delivered by Iacobucci J (Gonthier, Cory and Major JJ concurring). Although phrased in the language of compromise, a closer analysis reveals a total capitulation.

Two companies named Husky Oil ("Husky") and Bow Valley decided to pursue a drilling opportunity off the coast of Canada. One of Bow Valley's subsidiaries therefore contracted with Saint John Shipbuilding ("Saint John") for the construction of a drilling rig. In order to take advantage of offshore financing Husky and Bow Valley incorporated an offshore company, Bow Valley Husky Ltd ("BVH"), to which they transferred ownership of the rig before construction began. Husky and Bow Valley then entered into four year leases of the rig for drilling. These required that they pay BVH day rates even in the event that the rig was out of service.

Due to negligence by both Saint John and BVH a fire broke out on the rig and it was out of service for several months. Husky and Bow Valley sued for their wasted hire costs as well as additional expenses including food and equipment costs. As lessors using the rig, Husky and Bow Valley might ordinarily have recovered under the exclusionary rule as having a possessory interest in the rig. However, it was common ground that, under maritime law concepts, these particular leases did not give possession. All they gave Husky and Bow Valley was a contractual right to services from BVH, which supplied

76 Norsk above n 52, 344. This phrase is borrowed from Stevenson J, who also rejected the concept: Norsk above n 52, 386-387.

77 This uncertainty had led to interim cases being decided in accordance with both approaches: see for example D'Amato v Badger (1996) 137 DLR (4 $\left.{ }^{\text {th }}\right) 129$ (SCC). 
both the rig and (indirectly through a separate entity which ran the rig operations) the workers. $^{78}$

McLachlin J held that they could not recover. She began by emphasising the similarities between her own and La Forest J's judgment in Norsk. Her Honour stated that both she and La Forest $\mathrm{J}$ agreed that contractual relational economic loss is only recoverable in special circumstances which are defined by reference to categories and that these categories are not closed. Significantly, her Honour then set out La Forest J's "categories", which she described as the exclusionary rule with exceptions for certain admiralty cases $^{79}$ and joint ventures. McLachlin J concluded that the case at bar did not fall into any of the three categories. ${ }^{80}$ Her Honour then stated that: ${ }^{81}$

[w] here a case does not fall within a recognised category the court may go on to consider whether the situation is one where the right to recover contractual relational economic loss should nevertheless be recognised...At the same time, courts should not assiduously seek new categories; what is required is a clear rule predicting when recovery is available.

As a guide to the establishment of new categories, her Honour began a detailed analysis of La Forest J's judgment in the recent negligent misstatement case of Hercules Managements Ltd $v$ Ernst $\mathcal{E}$ Young. ${ }^{82}$ The Supreme Court treated this case as a claim for relational economic loss. McLachlin J described La Forest J's judgment in this case as upholding the "two-part methodology of Anns"83 and deciding that "the existence of a relationship of 'neighbourhood' or 'proximity' distinguishes those circumstances in which the defendant owes a ... duty of care to the plaintiff from those where no such duty

78 According to maritime law, only charters by demise give possession. These leases were not charters by demise (cf the charter in Rivtow Marine v Washington Iron Works (1973) 40 DLR (3d) 530). The Newfoundland Court of Appeal stated that: "[t]here is, in this case, no right to use the property of $[\mathrm{BVH}]$; rather it is a contractual right to have a service performed, the drilling of wells in places specified": Bow Valley Husky (Bermuda) Ltd v Saint John Shipbuilding Ltd (1995) 126 DLR (4 $\left.4^{\text {th }}\right) 1,42-43$ [Bow Valley Newfoundland CA]. See generally above $\mathrm{n} 28$.

79 Where the plaintiff is required to make a "general average" contribution. See Greystoke above n 45 .

80 Her Honour also rejects the suggestion that the plaintiffs suffered transferred loss from BVH: Bow Valley above n 53, 410. She does not state whether they would have recovered if they had.

81 Bow Valley above n 53, 406-407.

82 (1997) 146 DLR (4 th) 577 [Hercules].

83 Bow Valley above n 53, 408. 
exists". 84 McLachlin J declared this approach equally applicable to contractual relational economic loss. 85

In applying this test, her Honour found sufficient proximity to exist under the first step, but that the duty of care was negatived by "the policy concerns that usually preclude recovery of contractual relational economic loss". ${ }^{86}$ Essentially this was the indeterminacy problem: McLachlin J found that there was no principled way for Husky and Bow Valley to distinguish themselves from any other class of potential claimants. Her Honour also noted that this was a case where sophisticated parties knowingly allocated their risks beforehand. Under the leases with BVH, the risk of downtime specifically fell on Husky and Bow Valley.

So, what is the result? Does Bow Valley apply McLachlin J's proximity test or La Forest J's exclusionary rule? Iacobucci J confidently stated the latter: ${ }^{87}$

I understand my colleague's discussion of this matter to mean that she has adopted the general exclusionary rule and categorical exceptions approach set forth by La Forest J in Norsk.

This appears to be the correct assessment. Confirmation can be found by reading La Forest J's judgment in Hercules upon which McLachlin J relied so heavily. Although her Honour is correct that La Forest J does refer to proximity, her implication that this was in some way a compromise of his approach in Norsk is misleading. Indeed his Honour stated: 88

In approaching [the question of proximity], I would begin by reiterating the position I took in Norsk...that the term "proximity" itself is nothing more than a label expressing a result, judgment or conclusion: it does not, in and of itself, provide a principled basis on which to make a legal determination.

This is clear from the way in which he then used the proximity concept. He did so by defining, with reference to precedent and policy reasons, when liability will lie in negligent misrepresentation cases. ${ }^{89}$ He then labelled this result proximity. Proximity in Hercules indicates but certainly does not define, when liability exists.

\footnotetext{
84 Bow Valley above n 53, 408.

85 Bow Valley above n 53, 409.

86 Bow Valley above n 53, 409.

87 Bow Valley above n 53, 428.

88 Hercules above n 82, 588.

89 Hercules above n 82, 587.
} 
Therefore, although the language of the Anns-test has been retained, the substance of the test has not. The test McLachlin J applied in Bow Valley was the exclusionary rule. Her Honour only referred to the proximity concept later in deciding whether a cautious exception to the rule should be permitted.

Even then, this was only lip service. What happened in Bow Valley is what will almost always happen: proximity will be found to exist, but the usual policy considerations which support the exclusionary rule in the first place will then be invoked to negative liability. The Bow Valley test for when a new exception should be made is in substance the same as the test applied by La Forest J in Norsk: a bare analysis of policy factors. ${ }^{90}$ The only difference is that the word proximity has been inserted into its workings.

The point is that whatever proximity now describes, it is no longer the determinant of liability applied by McLachlin J in Norsk. If it were, then surely the result in Bow Valley would have been different. If the relationship between CNR and Canada could be labelled a joint venture and satisfy any negative policy concerns, the relationship between two companies and the shadow company they erect purely for tax purposes must also be a joint venture.

Indeed, many of the problems the Norsk case posed were conspicuously absent in Bow Valley. Unlike the public rail bridge used by four companies, the rig was private property and was used only by Husky and Bow Valley. Husky and Bow Valley also had a close relationship with the property owner BVH - they created and each owned shares in it. This is in contrast to the very distinct entities of CNR and Canada. Further, the leases between Bow Valley, Husky and BVH did not contain the clause found in CNR's contract with Canada which totally excluded Canada's liability to CNR in the case of damage to the bridge. Thus there was less basis from which to infer that the parties had definitively allocated their risks. It is submitted that the only explanation for the disparate results in Norsk and Bow Valley is that different tests were applied.

The Canadian test is now the exclusionary rule with exceptions for certain admiralty cases, joint ventures (however defined) and possibly for transferred loss cases. Where a situation falls inside the rule and outside the exceptions, there is a possibility that a new exception may be created if a sufficiently principled basis can be suggested. What is clear is that the case-by-case proximity approach has been quietly laid to rest. 


\section{ANALYSIS OF MERITS OF THE EXCLUSIONARY RULES}

\section{A What is Really at Issue: the Debate within the Debate}

It has been seen that England has continued to apply the exclusionary rule and that Canada has recently done so. Australia, on the other hand, has rejected the rule. New Zealand is somewhere in the middle, although it appears to be moving away from the rule.

To this point, this paper has shown which sides were chosen. The remainder of the paper reveals what the debate was really about. This insight owes a debt to the sophisticated Canadian analysis. McLachlin and La Forest JJ's disagreement in Norsk made explicit the real issue underlying debates about the exclusionary rule. The fundamental disagreement is not about the rule itself, but about the approach to negligence law the rule implies.

Essentially, the issue is the old chestnut of economic loss - the indeterminacy problem. Consideration of the exclusionary rule demands the answer to a far bigger question, namely: which device should be used to decide when economic loss will be recoverable?

Although the many judicial labels and careful distinctions imply otherwise, it is submitted - and this was recognised by both Canadian Judges - that in fact the cases reveal only two such devices. ${ }^{91}$ This article shall refer to these as the "proximity approach" and the "categorical approach". ${ }^{92}$

The proximity approach is epitomised by the Anns test and has two essential features. First, it is concerned with similarities: it works by distilling general principles from disparate cases. It is therefore a universal test which is equally applicable to different situations. Secondly, a proximity approach proceeds on a case-by-case basis. It does not control liability by reference to fixed rules, but with regard to general principles or

91 See Norsk above n 52, 366 per McLachlin J; 302, 344, and 356-357, per La Forest J. This basic distinction is also recognised by Lord Goff in Smith $v$ Littlewoods above n 5, 280; Bruce Feldthusen Economic Loss (1ed, Toronto, Carswell, 1984) 3; Hon Sir Anthony Mason in "The Recovery and Calculation of Economic Loss" in Nicholas Mullany (ed) Torts in the Nineties (LBC Information Services, North Ryde, 1997) 1, 4-6; Keith Stanton "Incremental Approaches to the Duty of Care" in Nicholas Mullany (ed) Torts in the Nineties, this note, 34, 34-37; and Karen Hogg Vaggelas "Proximity, Economic Loss and the High Court of Australia" (1997) 5 Tort L Rev 127, 127.

92 The point should be made again that this dichotomy groups together fundamentally similar but sometimes superficially different - approaches. It thus makes some reluctant bedfellows. For instance, while Lord Cooke has never been an enthusiast of the proximity criterion ("An Impossible Distinction" (1991) 107 LQR 46, 54), the approach he describes in South Pacific (above n 7) is, on this analysis, clearly a "proximity" approach. Again, although Australia has eschewed the Anns test because of its perceived emphasis on reasonable forseeability, on this analysis both Lord Wilberforce and the High Court of Australia share the same approach. 
considerations of what is "just and reasonable". 93 Therefore it is implicit that "proximity is not susceptible of an exact...definition"94 and this is part of its appeal.

The categorical approach, by contrast, is concerned with differences. Its starting point is Feldthusen's observation that "[w]ithin the category of claims for economic loss there exist more differences between and among the cases than similarities". ${ }^{95}$ It therefore does not seek to distil the general principles underlying negligence liability as a whole. Instead, at least with respect to pure economic loss, it replaces broad principles by category-specific rules and policy considerations. This approach can be currently seen in both Feldthusen's separate categories of economic loss and in the so-called "incremental approach" recently embraced by the House of Lords in Caparo Industries Plc $v$ Dickman. ${ }^{96}$

The debate about the exclusionary rule is inevitably based on these broader assumptions about how tort law should work. The reason is that the rule - far from being neutral - picks sides. Being particular to relational economic loss, the rule inherently implies a categorical approach based on different types of economic loss.

The effects of this can be seen in practice. Where the rule has been endorsed, as in England and Canada, a broad-based proximity approach has been concomitantly rejected. ${ }^{97}$ Where the rule has been rejected, the alternatives offered have been proximity tests. ${ }^{98}$ This makes sense. The main objection to the exclusionary rule is usually not to its specific content, but to its general nature. Typically, objectors are proximity adherents

93 See for example South Pacific above n 7, 297 per Cooke P; and Bruce Feldthusen "The Recovery of Pure Economic Loss in Canada: Proximity, Justice, Rationality, and Chaos" above n 65, 5.

94 Hon Sir Anthony Mason in "The Recovery and Calculation of Economic Loss" in Nicholas Mullany (ed) Torts in the Nineties above n 91, 4.

95 Bruce Feldthusen "The Recovery of Pure Economic Loss in Canada: Proximity, Justice, Rationality, and Chaos" above n 65, 3.

96 Caparo Industries Plc $v$ Dickman [1990] 2 AC 605. It can also be discerned from earlier English cases such as Muirhead v Industrial Tank Specialities Ltd [1985] 3 WLR 993.

97 Although both England and Canada reach a similar conclusion on contractual relational economic loss, their rules governing the recoverability of economic loss in general are of course different. Canada does not accept the wider exclusionary rule of Murphy above n 7: see Norsk above n 52, 303 per La Forest J; 365 per McLachlin J. Nevertheless, it is submitted that both jurisdictions apply a categorical approach - England just does so more bluntly, treating all economic loss (apart from negligent misstatement) as a single category.

98 See McLachlin J's judgment in Norsk above n 52 and the various approaches in Caltex above n 46. 
who fundamentally do not believe in controlling liability by categories. They see no value in absolute distinctions between different types of loss. ${ }^{99}$

In short, the two issues are inextricably linked. Subscribers to a categorical approach naturally support the exclusionary rule as the most appropriate control mechanism for contractual relational economic loss. Conversely, supporters of a proximity approach do not treat such loss as a distinct group. They naturally reject the rule as inconsistent with the case-by-case proximity analysis.

Therefore, the debate over the exclusionary rule is really about whether the proximity or the categorical approach should be preferred.

\section{B The Proximity Approach vs the Categorical Approach}

\section{The proximity approach}

Proponents of a proximity criterion argue that it is only this which lends negligence law a "unifying theme". ${ }^{100}$ Instead of applying rules to distinguish between claimants, proximity looks to the essence of when recovery was allowed in previous cases and makes reasoned analogies to later ones.

This process of analogy takes account of all relevant factors which establish the relationship between the plaintiff and the tortfeasor. It thus allows the structure of relationships to prevail over factual differences between cases. A good example is the "reliance" concept, first advocated as an indicator of proximity for negligent misstatement in Hedley Byrne. ${ }^{101}$ The High Court of Australia later used this same concept in the quite different contexts of council liability; ${ }^{102}$ professional negligent acts; ${ }^{103}$ and defective house construction. ${ }^{104}$

The proximity criterion is a healthy reaction to unreasoned, precedent-based restrictions on liability exemplified by Murphy. The proximity approach does not treat factual distinctions between cases, such as the exact form of loss suffered, or whether the

See Norsk above n 52, 366-367 per McLachlin J; Caltex above n 46, 567-572 per Stephen J: and 606 per Murphy J.

100 Burnie Port Authority v General Jones Pty Ltd (1994) 179 CLR 520, 543 per Mason CJ, Deane, Dawson, Toohey, and Gaudron JJ.

101 Above $\mathrm{n} 7$.

102 Sutherland Shire Council v Heyman (1985) 157 CLR 424.

103 Hawkins v Clayton (1988) 164 CLR 539.

104 Bryan v Maloney (1995) 182 CLR 609. For an example of reliance being used as a general indicator of proximity, see South Pacific above n 7, 300 per Cooke P. 
negligence is in the form of words or deeds, as decisive. Instead, a careful analysis of each case is undertaken to establish the closeness of the relationship. In Norsk, McLachlin J defined the approach in this way: ${ }^{105}$

Proximity may consist of various forms of closeness - physical, circumstantial, causal or assumed - which serve to identify the categories of cases in which liability lies.

Of course the proximity approach usually does not stop there. Another important limiting factor is often the consideration of any policy concerns which militate against the imposition of liability. This second step increases the flexibility of the test as a whole.

The flipside of this flexibility is of course a degree of uncertainty. La Forest J rightly pointed out in Norsk that McLachlin J's finding of proximity between CNR and Canada did not provide a clear rule of liability for future use. His Honour dismissed the test as having "practically no predictive value". ${ }^{106}$ While a decrease in certainty might be a reasonable price to pay for an increase in principle, it is debatable whether this is really what proximity delivers.

La Forest J's statement (which is perhaps an overstatement) hints at a deeper problem with proximity. This is that its lack of predictive value stems from its lack of basic content. Proximity often expresses a result, not a principle. This objection goes to the heart of the principled image which proximity cultivates and casts proximity as merely a label for an old-fashioned policy decision. ${ }^{107}$ This has long been Brennan J's outspoken position in the High Court of Australia. ${ }^{108}$

The ramifications of this are more serious than a lack of theoretical precision. The real problem is that proximity can appear to be merely a collection of unrelated factors which, when applied to specific situations, are of questionable relevance. An obvious example is the known plaintiff test applied by Gibbs J in Caltex, Stevenson J in Norsk and Barker J in New Zealand Forests. The fact that the defendant specifically knew of the plaintiff does make their relationship closer in some respects than if the defendant had been unaware of

105 Norsk above n 52, 369. This is a paraphrase of Deane J's famous passage in Sutherland Shire Council v Heyman above n 102, 497 in which his Honour outlined some of the many disparate factors which inform the concept.

Norsk above n 52, 354 .

This appears to be accepted by Cooke P in South Pacific above n 7, 299 where his Honour emphasised "the ineluctable importance of policy in this field".

However, since his Honour's ascension to Chief Justice it appears to be gaining increased acceptance. In the recent decision of Hill (t/a R F Hill \& Associates) $v$ Van Erp (1997) 124 ALR 68, three of the six judgments (those of Brennan CJ, McHugh and Gummow JJ) rejected the proximity concept for this very reason. 
the plaintiff's existence. But is this a relevant criterion on which to distinguish liability in a relational loss situation?

The answer is probably not. As La Forest J pointed out in Norsk, contractual relational economic loss is usually the result of an accident. ${ }^{109}$ It is not usually the result of a calculated risk known to be likely to affect the plaintiff. In negligent misstatement and products liability cases, for instance, the individuals foreseen by the tortfeasor as likely to rely on the advice or use the product are clearly relevant to the extent of the tortfeasor's liability. This is not so with a collision or other accident. In relational economic loss cases, the plaintiff's identity - far from being relevant to the defendant's liability - is an unconnected fact.

Further, the exact relevance of other common proximity factors such as physical and circumstantial closeness is also unclear. In the Norsk case, the finding of proximity was largely based on the fact that CNR was the preponderant user of the bridge and owned (undamaged) property nearby. Effectively, it was CNR's "status as the property owner's principal client"110 together with its long history of using the bridge which distinguished it from the other three railway companies with contracts to use the bridge. It is doubtful whether this was a principled distinction. In fact, such an analysis does not seem so distant from the known plaintiff test. If CNR had had a lower profile in the region, it too may not have recovered.

Thus although it is undeniable that the exclusionary rule makes arbitrary distinctions between plaintiffs, the same can also be said of the proximity approach. ${ }^{111}$ The hazy basis of proximity is often only apparent when the scale of a case changes. The New Zealand Forests case concluded with the disclaimer by Barker J that "[o]f the situation of a power failure in an urban area where thousands might be affected to a greater or lesser degree, I am not required to rule". ${ }^{112}$ This indicates that Barker J's ratio may not be appropriate to

109 Norsk above n 52, 302.

110 Robby Bernstein Economic Loss above n 8, 168.

111 See Norman Siebrasse "Economic Analysis of Economic Loss in the Supreme Court of Canada: Fault, Deterrence, and Channelling of Losses in CNR v Norsk Pacific Steamship Co" 20 Queens LJ 1,51 .

112 New Zealand Forests above n 16, 20. 
the Auckland power crisis. If so, the ratio lacks substance. A test for liability should not change in accordance with the number of potential plaintiffs. ${ }^{113}$

It appeared to do exactly this in a recent Australian case, Seas Sapfor Forests Pty Ltd v Electricity Trusts of South Australia. ${ }^{114}$ In this case an electrical Authority negligently started a bushfire. It was sued, inter alia, by millers of pine timber for relational economic loss suffered in the form of lost profits. The Authority was held not liable for the reason that "the class of persons who profit from handling or dealing in produce of land damaged by bushfires" is unascertainable. ${ }^{115}$

From the facts of the case it is hard to see why this was so. As Lord Fraser noted in The Mineral Transporter, a large class is not unascertainable simply because it is large.116 The result in Seas Sapfor Forests was thinly veiled expediency. The main judgment of Doyle CJ explicitly turned on the difference in scale between this and the Caltex case: "[t]he forests owned by the plaintiffs were not the only things affected, or likely to be affected, by an outbreak of fire. This is not the case of a specific pipe being broken; rather, it is a case of an entire countryside on fire". ${ }^{117}$

Both New Zealand Forests and Seas Sapfor Forests hint that proximity only really works in easy cases. They expose it as a crude attempt at justice rather than a principled analysis of neighbourhood.

\section{The categorical approach}

The argument against the categorical approach is that it is an abandonment of the unified approach to negligence liability begun in Donoghue $v$ Stevenson. It is argued that without a universal test underlying all negligence liability, negligence law will become a set of inconsistent and dislocated cases. Principle will be sacrificed for certainty. This

113 As La Forest J points out in Norsk above n 52, 338, this is precisely the problem which contractual relational economic loss causes for the proximity approach: "[t]he problem with this case from the perspective of indeterminate liability is that it involves a type of accident that will very likely lead to a great number of claims. It so happens, that on the facts of this case, the number of injured parties is small. The fact that Norsk was fortunate enough to hit a bridge with few users does not make its potential liability of contractual relational economic loss any less indeterminate."

Seas Sapfor Forests Pty Ltd v Electricity Trusts of South Australia (9 August 1996) unreported, Federal Court, South Australia, SCGRG 263 of 1989.

Seas Sapfor Forests above n 114, para 125 per Doyle CJ.

116 The Mineral Transporter above n 25, 24.

117 Seas Sapfor Forests above n 114, para 95. 
objection is central to the case against the exclusionary rule. Detractors observe that the rule is capricious and argue that its only merit is its simplicity.

It is true that the distinction it makes between physical and economic loss sometimes leads to bizarre outcomes. For instance the defendant in The Aliakmon was happily relieved of liability for the cargo damage it undoubtedly caused. The unusual contractual arrangement between the buyer and the seller of the cargo meant that the buyer, who had the interest in suing, had no right to, whilst the seller, who had suffered no loss, retained a right to recover. Similarly in The Mineral Transporter, the fact that the owner had demised and rechartered its own boat meant that the defendant escaped liability for loss which would have been recoverable had the owner not demised the vessel in the first place.

Further, when the need for a possessory or proprietary interest is combined with the rule allowing recovery of economic loss consequent on physical damage, it is undeniable that "physical damage, however minuscule" makes all the difference. ${ }^{118}$

The basis for the categorical approach towards economic loss cases is that economic loss can be caused in "various ways with different consequences". ${ }^{119}$ Thus the mechanism controlling liability should focus on these differences, not try to extract similarities from dissimilar situations. In particular, the categorical approach vehemently denies that to call loss "economic" is, of itself, a meaningful description. ${ }^{120}$ A tendency to generalise from one type of economic loss to another simply leads to the creation of confused reasons for liability. Essentially the need for categories is that good reasons for when liability is allowed in one category are not necessarily translatable to another.

It follows that this approach does not entail a rejection of a unifying theme of negligence liability. It still endorses the Donoghue v Stevenson neighbourhood principle. The categorical approach simply accepts that one's neighbours vary according to where one lives. Instead of providing the same test of neighbourhood for all situations, it adapts that test for specific types of case. It is not true to say that it sacrifices principle for certainty. It merely identifies precise bases for principled distinctions.

A clear example of why these are needed has already been mentioned in the discussion of proximity. The relevance of a known plaintiff to negligent misstatement

118 Norsk above n 52, 359 per McLachlin J.

119 Hon Sir Anthony Mason in "The Recovery and Calculation of Economic Loss" in Nicholas Mullany (ed) Torts in the Nineties above n 91, 5 .

120 Bruce Feldthusen "The Recovery of Pure Economic Loss in Canada: Proximity, Justice, Rationality, and Chaos" above n 65, 2. 
and products liability cases is clear. Its relevance to relational economic loss cases is not. Feldthusen's five categories $^{121}$ distinguish between quite different situations. The categorical approach provides the opportunity to make relatively certain rules for liability without reliance on irrelevant factors.

There are at least three unique policy considerations which make the exclusionary rule appropriate for contractual relational economic loss. The first is that such loss always occurs in situations where the tortfeasor is already liable to the property owner. The effect of this is important in that "the deterrent effect of tort law...is already present". ${ }^{122}$ Thus, as Feldthusen points out, the question is not whether the tortfeasor should be held liable in negligence, but whether additional liability should be imposed. ${ }^{123}$

The second reason is that contractual relational economic loss cases, by definition, involve contracts. Plaintiffs have had the opportunity to consider how valuable their contractual rights are and how, if at all, they should protect them. If the rights are important, plaintiffs will typically have bargained for a contractual indemnity or factored the price of first-party insurance into the negotiations. There are of course many ways contractual rights may be disrupted, from natural causes to human error. This fact must form part of any responsible contractual negotiations. Further, for such plaintiffs, certainty is perhaps as important as justice. It is far easier to negotiate for protection with knowledge of the default rules.

The point is that contractual relational economic loss plaintiffs are typically sophisticated insured parties suing a defendant who is already liable for the damage caused. What is needed is not so much a rule to punish, but a rule to allocate often unavoidable losses of day to day life.

The most important factor, though, is that most contractual relational economic loss plaintiffs cannot recover under any other approach. The risk of indeterminate liability is

121 For the categories, see above n 65.

122 Norsk above n 52, 301. It is of course possible that the actual physical damage inflicted will be less than the relational economic loss suffered, a point noted by Siebrasse "Economic Analysis of Economic Loss in the Supreme Court of Canada: Fault, Deterrence, and Channelling of Losses in CNR $v$ Norsk Pacific Steamship Co" above $\mathrm{n} 111,36$. In such a case there will be deterrence value in the additional liability which could be imposed. This is a good point. The two answers to it are first that any exclusionary rule should be flexible enough to take account of unusual cases; and second, that the problem is more theoretical than real. Ordinarily there would be some degree of correlation between the two types of loss. Presumably, little physical damage would usually cause relatively slight economic loss.

123 Bruce Feldthusen "Economic Loss in the Supreme Court of Canada: Yesterday and Tomorrow" above $n 64,377$. 
simply far larger with contractual relational economic loss than it is with any other form of economic loss. Clear limits must be imposed. As Feldthusen points out: ${ }^{124}$

Every time there is injury to person or property, there will be an indeterminate number of persons whose immediate economic interests may be damaged.

A rule generally precluding liability is sensible. The unique features of contractual relational economic loss provide a good answer to claims that the exclusionary rule is unprincipled and expedient. The rule is harsh, but it is not unfair.

\section{Conclusion}

The special relevance of the indeterminacy problem to contractual relational economic loss is a challenge that the proximity test is unable to convincingly answer. As Bernstein puts it: ${ }^{125}$

While it is easy to criticise the exclusionary rule...it must be appreciated that, whichever other alternative theory, or test, is applied, recovery will still be denied to the vast majority of relational economic loss sufferers.

If not by a general prohibition with careful exceptions, how else should the courts separate some parties with contractual claims over property from all of the others without opening the floodgates? A broad case-by-case approach has not shown that it can pick out one claimant from another in a principled way. Why, for instance, should CNR recover but not the other railway companies?

It is submitted that only a categorical approach both reacts to the indeterminacy issue and pinpoints relevant and limited grounds for recovery. The exclusionary rule is by no means perfect. However, so long as it is tempered by carefully formulated exceptions, it is still the most principled, certain, and efficient way of sorting the lucky few from the rest.

\section{The Form of the Exclusionary Rule}

If the categorical approach and therefore the exclusionary rule is preferred, thought must be given to its precise shape. Appropriately drafted exceptions can ameliorate much of the rule's perceived injustice. It is submitted that these should be wider than in most current forms of the rule.

124 Bruce Feldthusen "The Recovery of Pure Economic Loss in Canada: Proximity, Justice, Rationality, and Chaos" above n 65, 17.

125 Bernstein Economic Loss above n 8, 178. See also John Fleming "Economic Loss in Canada" (1993) 1 Tort L Rev 68, 74, who also reaches this conclusion. 
First, the rule should be subject to the two generally acknowledged exceptions for certain admiralty cases ${ }^{126}$ and joint ventures. However the definition of joint venture should be wider than that adopted by the Canadian Supreme Court. The Court in Bow Valley held that the two oil drilling companies, Bow Valley and Husky, were not in a joint venture with $\mathrm{BVH}$; the company they created to own the rig. The reason was given more fully in Norsk: a joint venture only arises where both parties own (or at least operate and maintain) the damaged property. ${ }^{127}$ Bow Valley and Husky did not have any property rights or obligations in respect of the rig.

It is submitted that, in this context at least, this definition is too narrow. Clearly if Bow Valley and Husky had shared between themselves ownership and management of the rig, they would have been in a joint venture. However instead of using the same entity to both own and use the rig, they cleanly split ownership and use. Their subsidiary company would own the rig, but they would use it. This is simply a different way of achieving the same practical result. It is submitted that a joint venture should not require joint property ownership but should also recognise structural control. That is, a joint venture should be found to exist between any company and a subsidiary in which the company is a controlling shareholder, where the latter owns the property which the former contractually uses.

Thus if Bow Valley and Husky had held a controlling interest in BVH, this should have constituted a joint venture. In this situation there is still only one project - to use the rig to drill for oil. The difference is simply that instead of jointly owning the rig, the users would jointly own the owner of the rig. In the event, Bow Valley and Husky did not own BVH. At the time of the fire, neither (either separately or jointly) held more than half of the shares in the holding company which $100 \%$ owned BVH. ${ }^{128}$ Nor did they have indirect control over this holding company.

It is submitted that the result in the case was therefore correct. In the absence of a clear right to control BVH, Bow Valley and Husky's interest was primarily a contractual right to use property belonging to a separate party. Although their intention to use the rig to drill for oil is clear, they did not express this intent through either the ownership of the rig, or

That is, 'general average' cases: see above n 45 and n 79.

Norsk above n 52, 332 per La Forest J.

BVH was actually $100 \%$ owned by BVHOH, which in turn was owned $34.96 \%$ by Husky and $64.96 \%$ by BVRS, a subsidiary of Bow Valley. However, Bow Valley owned only $41.5 \%$ of BVRS. Thus BVRS and not Husky or Bow Valley, owned the majority of shares in BVHOH. As Bow Valley did not own more than half of the shares in BVRS, neither it nor Husky could command a controlling interest in BVHOH or, indirectly, BVH. See Bow Valley Newfoundland CA above $\mathrm{n}$ $78,15,60$. 
their relationship with the rig's owner. Bow Valley and Husky carefully structured their relationship with BVH for tax purposes. They should not have the best of both worlds. If the corporate veil is firmly lowered for tax reasons, it should not be lifted in a tort context. It was open to Bow Valley and Husky to form a joint venture of some sort with BVH. They intentionally did not do this.

Second, an exception should be made for transferred loss cases. Although this was rejected by the House of Lords in The Aliakmon, and not expressly accepted by the Supreme Court of Canada, it makes sense and is not problematic in the narrow definition given by La Forest J. Lord Goff's revival of this concept in the recent House of Lords case of White $v$ Jones $^{129}$ concerning negligence affecting intended beneficiaries under a will adds impetus to this argument. Where the risk of property damage has been assigned to the plaintiff, the plaintiff has all the interest in suing and the owner has none. There is little problem of indeterminate liability and a real risk that the tortfeasor will be underdeterred as a result of not being made to pay for the property actually damaged. In other words, where property is damaged, someone should have both a right and an interest to sue for that damage. The transferred loss exception ensures this.

Third, a strong case could also be made for time charterers, whose exclusion even La Forest J admits appears "capricious". 130 In many respects contracts of carriage differ from contracts of hire and can probably be distinguished from the latter without creating unlimited liability. ${ }^{131}$ Cargo carriers such as ships are almost always in use by someone and usually by only one party. Sometimes this party is the owner. Frequently it is not. However some loss of use will almost always result from the physical damage. This loss of use is thus routinely predictable. If a party damages a cargo ship, it should have to pay for the almost inevitable economic loss caused to the carrier - whoever this might be.

Finally, the rule cannot be inflexible. There must be scope for further exceptions, although these must be made with care so as not to undermine the certainty of the rule. The essence of the test applied in Bow Valley, that an exception be made only when the negative policy considerations that "usually preclude recovery of contractual relational economic loss...are overridden"132 seems appropriate. Specifically, in accordance with La Forest J's suggestion in Norsk, the plaintiff should attempt to:

White v Jones [1995] 2 AC 207, 264-266.

Norsk above n 52, 356

Michael Jones "Economic Loss - A Return to Pragmatism" [1986] 102 LQR 13, 17. Feldthusen appears to agree: Bruce Feldthusen Economic Negligence (1ed) above n 91, 247.

Bow Valley above n 53, 409. 
(a) address the indeterminacy problem; and

(b) (i) either show that the deterrent effect of potential liability to the owners property is low; or

(ii) show that the plaintiff's opportunity to allocate risk by contract is slight.

If this can be done, then there would seem little objection to carefully extending the ambit of the defendant's liability.

\section{CONCLUSION}

The aim of this paper has been to show that the choice of whether or not to adopt the exclusionary rule is a choice about how to control negligence law generally. This perennial problem is relevant to New Zealand as the case law is currently equivocal as to whether the exclusionary rule is still good law. Overseas jurisdictions, while not so equivocal, are not all in agreement. What all of the cases have shown is that the issue over the exclusionary rule is, in reality, a choice about approach. Specifically, a choice between the broad, case-by-case test of proximity and the categorical approach dividing different types of economic damage into different groups.

This paper has argued that the second is the most principled approach - the one which is most able to isolate meaningful reasons behind the outcomes it provides - and that the adoption of this approach naturally leads to the acceptance of a general exclusionary rule for contractual relational economic loss. As La Forest J stated: "[t]he court should do more than simply establish a rule that allows judges to resolve cases as they see fit". 133

This latter result is, in effect, the current New Zealand approach established by the Court of Appeal in Brown and South Pacific. If this approach is to be continued, the logical conclusion is for the exclusionary rule to be rejected. However it is submitted that such a broad approach is not sufficiently sophisticated to accommodate the complexities of modern negligence law.

One thing is clear. If and when - possibly as a result of the Auckland power crisis the issue of whether New Zealand should retain the exclusionary rule comes again for judicial consideration, the choice will be larger than it might appear. It will be whether to modernise negligence law by reference to clear principles, or to retain it as an unrefined tool of judicial policymaking. 